\begin{tabular}{|c|c|c|}
\hline & Int.J.Curr.Microbiol.App.Sci (2016) 5(11): 275-283 & \multirow{4}{*}{ 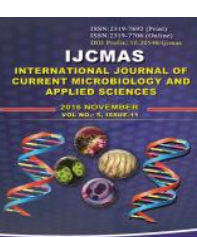 } \\
\hline & \multirow{4}{*}{$\begin{array}{l}\text { International Journal of Current Microbiology and Applied Sciences } \\
\text { ISSN: 2319-7706 Volume } 5 \text { Number } 11 \text { (2016) pp. 275-283 } \\
\text { Journal homepage: http://www.ijcmas.com }\end{array}$} & \\
\hline & & \\
\hline EXCELLENT & & \\
\hline PUBLISHERS & & wwwijemas.com \\
\hline
\end{tabular}

Original Research Article

http://dx.doi.org/10.20546/ijcmas.2016.511.030

\title{
Regulation of Ethylene Level in Mungbean (Vigna radiata L.) by 1- Aminocyclopropane-1-Carboxylic Acid (ACC)-Deaminase containing Bacterial Strain under Salt Stress
}

\author{
Sarita Kumari $^{1,2}$, Anukool Vaishnav ${ }^{1,2}$, Shekhar Jain ${ }^{1,2}$, \\ Devendra Kumar Choudhary ${ }^{2}$ and Kanti Prakash Sharma ${ }^{1 *}$
}

${ }^{1}$ Department of Biological Science, College of Arts, Science and Humanities (CASH), Mody University of Science \& Technology, Lakshmangarh, Sikar 332311, Rajasthan (India)

${ }^{2}$ Amity Institute of Microbial Technology (AIMT), Block 'E-3', 4th Floor, Amity University

Campus, Sector-125, Noida-201303, Gautam Buddha Nagar, UP (India)

*Corresponding author email id: kantipsharma@ rediffmail.com

Keywords

ACC-deaminase.

Ethylene

biosynthesis.

Mungbean.

Pseudomonas.

Salinity.

Article Info

Accepted:

16 October 2016

Available Online:

10 November 2016
A B S T R A C T

This study explored several features related to salt tolerance in mungbean plants through plant growth promoting bacteria (PGPB) Pseudomonas simiae strain AU. We report the significant effect of 1-aminocyclopropane-1-carboxylate deaminase on the physical parameters and biomass content of Vigna radiata as compared control seedling under salt stress. Control (plants devoid of bacterial strains) and PGPB inoculated mungbean plants were grown in soil: peat (1:1) subjected with saline and non-saline conditions. Results showed that PGPB inoculated plants had superior ability to tolerance against salt stress, as exposed by their enhanced plant biomass (Fresh weight), higher water content, higher photosynthesis activity and lower osmotic stress injury (Table 2). The increased proline accumulation in PGPB inoculated plants root contributed to increased plant tolerance to salt stress (Fig. 1). These results suggest that, in PGPB-inoculation plays a role in mitigate the adverse effect of salt stress. Furthermore, enhanced proline maintain an osmotic balance to keep a positive water potential for water entrance into the roots and reduce oxidative damage by lowering reactive oxygen species level under salt stress condition. Our results indicate that Pseudomonas simiae strain AU is multifunctional PGPB strains that can promote plant growth, development and reduce salinity stress by decreasing the stress ethylene level.

\section{Introduction}

The plant hormone ethylene is a gaseous hormone which is found in the all higher plants is an important modulator for normal plant growth and developmental process as well as a key feature in the response of different abiotic and biotic stresses (Abeles et al., 1992). Ethylene is an inhibitor for plant growth but at very low concentration it may promote plant growth in a large number of ways such as promoting root initiation in many plant species including Arabidopsis (Pierik et al., 2006). In the presence of wide range of environmental stresses like salinity (Mayak et al., 2004a), drought (Mayak et 
al., 2004b), temperature stress (Ghosh et al., 2003) metal stress (Belimon et al., 2009) etc., ethylene production may increases, this stress level of ethylene inhibit the root and shoot elongation, inhibiting root nodule formation, decreasing plant-microbe interaction, and inhibiting seed germination (Abeles et al., 1992). Hirsch and Fang (1994) reported that leguminous plants produced more ethylene, adversely affects the nodule formation.

Salinity stress extensively associated with elevated release of endogenous ethylene in higher plants which responsible for growth inhibition. Mayak et al., (2004a) have been reported the effect of soil salinity on the inhibited growth of plant roots and nodule formation in legumes due to high production of ethylene. Many other researchers also report the concentration dependent effect of salinity on seedling growth, increase in ethylene production with increasing level of salinity (Ahmad et al., 2011). The ACC content and ACC oxidase activity were increased due to increasing level of salinity. Many researchers experimentally provide that the induced level of ethylene have been reduced by the using plant growth promoting bacteria (PGPB) containing ACC-deaminase (Glick 2004; Mayak et al., 2004a). The use of PGPB-containing ACCdeaminase to improve plant growth in many crops has been increased worldwide. ACC deaminase-containing bacteria significantly decrease the portion of physiological damage in plants due to environmental stresses including exposure to extremes of temperature, high salt, flooding, drought, exposure to metals and organic contaminants. PGPB contain an enzyme ACC-deaminase lowers the stress ethylene level by conversion of ACC into ammonia and $\alpha$-ketobutyrate in the plants (root and seed) (Glick 2012). Belimov et al., (2009) studied that PGPB containing ACC- deaminase enhanced plant growth, particularly under stressed conditions by the regulation of increased ethylene production in response to abiotic and biotic stresses. Glick (2012) was described a scheme to mechanism of action of ACC-deaminase to reduce the stress ethylene level by catalytic conversion of ethylene precursor ACC that includes cyclopropane ring fragmentation, and deamination of ACC to from $\alpha-$ ketobutyrate and ammonia.

Legumes such as Vigna radiata (mung bean) serve as a major source of food protein in most of the Asian countries including India. It is also agriculturally important as a rotational crop, as it can fix the unavailable atmospheric $\mathrm{N}_{2}$ through root nodules in association with Rhizobia. Based on the previous findings and reports, we decided the aim of present study that was to investigate the effect of Pseudomonas simiae (MTCC-12057) bacterial strain AU on mungbean growth and salt stress tolerance. We found that bacterial inoculum showed better plant growth, decrease ethylene level and improved salt stress tolerance compared to non-inoculated plants.

\section{Materials and Methods}

\section{Bacterial strain and growth}

Pseudomonas simiae strain AU (NCBI accession no. KJ511869, MTCC no. 12057) was used in the present study and maintained on nutrient broth (NB, Himedia, India) amended with $50 \%$ glycerol at $-20^{\circ} \mathrm{C}$. Bacterial strain was grown in nutrient broth amended with different concentration of $\mathrm{NaCl}$ (50mM-300mM) and examined their tolerance level (Jha and others 2010). Inoculum for the seed treatment was prepared by harvesting bacterial cells from $24 \mathrm{hrs}$ cultures on nutrient agar plates at 
$26^{\circ} \mathrm{C}$. The inoculum was suspended in sterile distilled water to yield $10^{8}$ colonyforming units (CFU) per ml. We checked the susceptibility assay for the seeds of mungbean to growth at different salt concentrations and found that seedling growth was retarded at $100 \mathrm{mM}$ and $200 \mathrm{mM}$ $\mathrm{NaCl}$ concentration. On the basis of above described reason we have selected $100 \mathrm{mM}$ and $200 \mathrm{mM} \mathrm{NaCl}$ concentrations for further study.

\section{Quantification of ACC-deaminase activity}

ACC deaminase activity was determined by measuring the amount of $\alpha$-ketobutyrate produced by the cleavage of ACC by ACC deaminase (Penrose and Glick 2003). Both bacterial strains were grown on DF (Dworkin and Foster 1958) salt minimal media supplemented with $3 \mathrm{mM}$ of ACC or $0.1 \mathrm{M}$ of $\left(\mathrm{NH}_{4}\right)_{2} \mathrm{SO}_{4}$ for $48 \mathrm{~h}$. The experiment was arranged into three different culture conditions. These were as following- 1 . Bacterial culture and DF salt ( $\mathrm{N}$ source absent) 2. Bacterial culture $+\mathrm{ACC}$ as a nitrogen source and DF salt media. 3. Bacterial culture + ACC as a nitrogen source $+\mathrm{NaCl}(50 \mathrm{mM}, 100 \mathrm{mM}, 200 \mathrm{mM}$ and $300 \mathrm{mM}$ ) and DF salt. The bacterial cells were harvested by centrifugation at $10,000 \mathrm{rpm}$ at $4^{\circ} \mathrm{C}$ for $10 \mathrm{~min}$, washed twice with $0.1 \quad \mathrm{M}$ Tris- $\mathrm{HCl}$ (pH 7.5), and resuspended $0.1 \mathrm{M}$ Tris- $\mathrm{HCl}(\mathrm{pH}$ 8.5). The cells were labialized by $5 \%$ toluene $(\mathrm{v} / \mathrm{v})$ and then vortex at the highest speed for 1 min. The mixtures containing $1 \mathrm{ml}$ supernatant and $3 \mathrm{mM}$ ACC were incubated for $1 \mathrm{~h}$ at $28^{\circ} \mathrm{C}$. The samples were then mixed thoroughly with $500 \mu \mathrm{L}$ of $0.56 \mathrm{~N}$ $\mathrm{HCl}$ by vortexing, and the cell debris was removed by centrifugation at $10,000 \mathrm{rpm}$ for 10 minutes. A $500 \mu \mathrm{L}$ aliquot of the supernatant was transferred into glass test tube and mixed with $400 \mu \mathrm{L}$ of $0.56 \mathrm{~N} \mathrm{HCl}$ and $150 \mu \mathrm{L}$ of DNF solution $(0.1 \mathrm{~g} 2,4-$ dinitrophenylhydrazine in $100 \mathrm{~mL}$ of $2 \mathrm{~N}$ $\mathrm{HCl}$ ) and the mixture was incubated at $30^{\circ} \mathrm{C}$ for 30 minutes. One $\mathrm{ml}$ of $2 \mathrm{~N} \mathrm{NaOH}$ was added to the sample before the absorbance at $540 \mathrm{~nm}$ was measured. The concentration of $\alpha$-ketobutyrate in each sample was determined by comparison with a standard curve generated as follows: $500 \mu \mathrm{L} \alpha$ ketobutyrate solutions of $0,0.01,0.05,0.1$, $0.2, \quad 0.5, \quad 0.75$ and $1 \mathrm{mM}$ were mixed respectively with $400 \mu \mathrm{L}$ of $0.56 \mathrm{~N} \mathrm{HCl}$ and $150 \mu \mathrm{L}$ DNF solution. One $\mathrm{ml}$ of $2 \mathrm{~N} \mathrm{NaOH}$ was added and the absorbance at $540 \mathrm{~nm}$ was determined as described above. We observed that the $P$. simiae strain $\mathrm{AU}$ was showed ACC-deaminase activity at all $\mathrm{NaCl}$ stress concentration (Table 1).

\section{Plant growth conditions under salt stress}

To check the effect of $P$. simiae strain AU on mungbean plant under drought stress, six experimental groups designed wherein six replication per treatment were used. The bacterial inoculum was suspended in sterile physiological saline $(0.9 \% \mathrm{NaCl})$ to yield $1 \times 10^{8} \mathrm{CFU} \mathrm{ml}{ }^{-1}$. Mungbean seeds were used for the pot trial experiment. For surface sterilization, seeds were treated with $70 \%$ ethanol for 3 minutes and $0.1 \% \mathrm{HgCl}_{2}$ for 1 minute and washed with 3 times milli Q water after each treatment. After surface sterilization seeds were inoculated with $P$. simiae strain AU $0.1 \%$ carboxy methyl cellulose (CMC) for $3 \mathrm{~h}$ according to Ahmad et al., (2011). For control, seeds were soaked in sterile water for the same period of time. After $3 \mathrm{~h}$ incubation period seeds were sown into pots. Mungbean seeds were placed in autoclaved soil: peat $(1: 1)$ at equal distance of each other. Seeds were allowed to germinate in the dark in a growth chamber at $28^{\circ} \mathrm{C}$ for three days. After seed germination, pots were transferred to light with photoperiod of $16 \mathrm{~h} / 8 \mathrm{~h}$ light/dark and temperature $28^{\circ} \mathrm{C}$. After 8 days seedlings 
were treated with Hoagland's solution containing $100 \mathrm{mM}$ and $150 \mathrm{mM} \mathrm{NaCl}$ and these conditions were maintained for 7 day. Control seedlings were kept in Hoagland's solution without $\mathrm{NaCl}$. Based on the bacterial inoculation and $\mathrm{NaCl}$ treatment four experimental groups [Control (T1), $100 \mathrm{mM} \mathrm{NaCl}$ stress (T2) $200 \mathrm{mM} \mathrm{NaCl}$ stress (T3), AU-inoculated (T4), AU + $100 \mathrm{mM} \mathrm{NaCl}$ (T5); $\mathrm{AU}+200 \mathrm{mM} \mathrm{NaCl}$ (T6)] were designed. After treatment for 7 days, the mungbean seedlings were sampled and transferred at $-80^{\circ} \mathrm{C}$ until the measurement of variables under study.

\section{Monitoring plant growth parameters}

Inoculated seedlings and their corresponding non-inoculated control were harvested and root length, shoot length and fresh weights were measured. To measure leaf relative water content (RWC), fresh weighed (FW) $2^{\text {nd }}$ trifoliate leaves were used and floated the leaves tissue in distilled water for $24 \mathrm{~h}$ at room temperature in a dark place. Then measured the turgid weight (TW) along with dry weight (DW) for oven dried leaves treated at $80^{\circ} \mathrm{C}$ for $48 \mathrm{~h}$. RWC was calculated by equation (Mayak et al., 2004a): RWC=FW-DW/TW-DW $\times 100$

\section{Proline and total soluble sugar analysis}

Free proline content was measured by spectrophotometric analysis at $520 \mathrm{~nm}$ according to modified method of Bates et al., (1973) using acid ninhydrin reagent. Amount of proline was determined by using a standard curve of known concentration of L-proline and expressed as $\mu \mathrm{g} / \mathrm{gFW}$. Total soluble sugar(TSS) were analyzed by $0.1 \mathrm{ml}$ of the alcoholic extract of leaves and roots of different treatments reacting with $3 \mathrm{ml}$ freshly prepared anthrone (200 $\mathrm{mg}$ anthrone $+100 \mathrm{ml}$ of $72 \% \mathrm{H}_{2} \mathrm{SO}_{4}$ ) and incubated at $100^{\circ} \mathrm{C}$ in a boiling water bath for $10 \mathrm{~min}$ according to Irigoyen et al., (1992). After cooling at room temperature, the absorbance was read at $620 \mathrm{~nm}$ in a spectrophotometer and the TSS concentration was measured using standard curve of glucose in the range of $20-400 \mu \mathrm{g} / \mathrm{ml}$ and concentration of TSS in plant samples was expressed in $\mu \mathrm{g} / \mathrm{gFW}$.

\section{Ethylene production in response to stress}

For the detection of ethylene, six seeds for each treatment (T1, T2, T3, T5 and T6) were placed in respective $25 \mathrm{ml}$ flask on sterile filter paper. Seeds were sterilized and then imbibed in water for control and bacterial suspension (0.2 O.D.) of P. simiae AU for 2 $\mathrm{h}$ before being placed in the flasks. After 6 days, when the cotyledons expanded, $100 \mathrm{mM}$ and $150 \mathrm{mM} \mathrm{NaCl}$ applied for salt stress induction and kept each flask for $24 \mathrm{~h}$ and then closed for $2 \mathrm{~h}$ using a rubber septum. A $1 \mathrm{ml}$ sample of the headspace air from each flask was injected into a gas chromatography (Shimadzu - GC 2010) equipped with flame ionization detector (FID) stainless steel fused capillary column RTX 5 MS $(30 \mathrm{~m}$ x $320 \mu \mathrm{m}$ i.d., film thickness $0.25 \mu \mathrm{M})$. The amount of ethylene production was calculated by using the standard curve of pure ethylene and the concentration of ethylene in samples was expressed as pmol h $\mathrm{h}^{-1} \mathrm{FW}$.

\section{Statistical analysis}

For statistical analysis, randomized block design (RBD) was employed to investigate error in experimentation with a $2 \times 3$ factorial arrangement was used that include: two conditions (well water and drought) and three treatments (control: devoid of bacterial inoculation, AU inoculation, and AU-M4 inoculation).Plant growth parameters data were analyzed by Two way ANOVA analysis followed by Tukey's multiple comparison test. Remaining experiments 
such as ethylene detection, stomatal size measurement and bacterial PGP properties were done only under drought condition. Hence, these data were analyzed by One way ANOVA analysis followed by DMRT multiple comparison test. All analyses described were performed in SPSS software (SPSSInc., Version 16.0, Chicago, IL). Results were discussed in terms of percentage variation, with respect to control.

\section{Results and Discussion}

\section{Effect of bacterium inoculation on} mungbean growth attributes

The ameliorative effect of PGPB on the mungbean plant growth and its allied attributes were assessed under slight $(100 \mathrm{mM} \mathrm{NaCl})$ and moderate $(200 \mathrm{mM}$ $\mathrm{NaCl}$ ) salinity stress. With $100 \mathrm{mM} \mathrm{NaCl}$ stress the increase for shoot length was $16 \%$ and while at $200 \mathrm{mM} \mathrm{NaCl}$ the increase was $40.35 \%$ on the inoculation of AU (Table 2). Similarly, promotion of root length under salt stress was $31 \%$ and $70 \%$ with strain AU, under $100 \mathrm{mM}$ and $200 \mathrm{mM} \mathrm{NaCl}$ stresses respectively (Table 2). Plant fresh weight was increased by bacterial inoculation by $15.4 \%$ and $85.7 \%$ at $100 \mathrm{mM}$ and $200 \mathrm{mM}$ $\mathrm{NaCl}$ salt stresses respectively. Exposure to salinity stress adversely influences the plant RWC. The non-inoculated control plants had significantly lower RWC as compared to bacterial strain AU application during normal growth conditions. Relative water content of control plants was $45.9 \%$ at nostress lower than the AU inoculated plants, respectively. However, this effect was more prominent in non-inoculated control plants under salinity.

Free proline and total soluble sugars accumulation

Our findings indicated that under saline stress, bacterial inoculated plants were synthesized proline to a greater extent (Fig. 1). However, the proline content in with slight and moderate salinity was increased in compared to non-stressed conditions. In the present study, bacterial inoculated seedlings root accumulated $35.8 \%$ and $60.5 \%$ higher proline content under $100 \mathrm{mM}$ and $200 \mathrm{mM}$ salt stress levels (Fig. 1). Similarly TSS content was also recorded higher to $25.2 \%$ and $54.8 \%$ for $\mathrm{AU}$ inoculated plantlets root tissue than non-inoculated plant roots in $100 \mathrm{mM}$ and $200 \mathrm{mM} \mathrm{NaCl}$ salt stress respectively (Fig. 1).

\section{Effect on ethylene level}

In the present study ethylene level was increased in mungbean plantlets under salt stressed conditions. However, bacterial inoculated seedlings exhibited with lower ethylene content during salt stress because of their ACC-deaminase activity that degrade ethylene precursor in mungbean seedlings. $P$. simiae AU inoculated plant showed $41.6 \%$ and $50 \%$ lower ethylene content than non-inoculated seedlings under $100 \mathrm{mM}$ and $200 \mathrm{mM} \mathrm{NaCl}$ stress respectively (Fig.2).

High salinity in the agriculture sector is worldwide problem. Salinity stress is plant growth inhibitory in many crops. Mungbean is salt sensitive legume food crop; it has been documented that when mungbean plants are exposed to high levels of salt stresses their ethylene production is increased. ACC deaminase-containing plant growth-promoting bacteria have been reported to facilitate plant growth under salt stress by reducing the stress ethylene level that is produced as a consequence of abiotic stress (i.e. salt stress, drought stress etc) (Ali et al., 2014). In the present study, one plant growth-promoting bacterial strain $P$. simiae AU is used. As discussed earlier, ACCdeaminase is a key enzyme, produced by 
bacteria, which helps in ameliorating the plant stress under a variety of abiotic and biotic stress conditions (Kumari et al., 2015). When the mungbean seeds were treated with the plant growth-promoting ACC-deaminase containing bacterial strains ( $P$. simiae $\mathrm{AU}$ ), the emerging plant was ready to deal with a number of stresses more effectively and provided better protection against both type of stresses. Even in the absence of any stress, mungbean seeds inoculated with the bacterial strain AU showed better growth when compared to the control plants (no bacterial treatment) (Table 2 ). In the present study we found that the selected $P$. simiae strain AU was positively enhanced the mungbean plant growth parameters and increase the induced systemic salt tolerance. Hence, bacterial inoculation with plants is most effective strategy under stressed environment to increase plant growth and productivity (Ali et al., 2014). It has been suggested that containing ACC-deaminase bacteria to maintain stressed ethylene level and confers tolerance to various environmental stresses (Glick et al., 1998). This suggestion is supported by the result of the present study (Fig. 2) and also those that were reported previously by many researchers demonstrating induced tolerance level to salt stress, flooding stress, and heavy metal resistance (Mayak et al., 2004a). Roots plays major role in salinity tolerance in plants by modifying their anatomical and morphological parameters. Here, plants inoculated with strain AU showed higher shoot and root length compared to control plants (Table 2) under both $\mathrm{NaCl}$ salt level.

Table.1 ACC-deaminase activity of selected bacterial strain $P$. simiae strain AU under different $\mathrm{NaCl}$ concentrations. Values represent the mean $\pm \mathrm{SE}, \mathrm{n}=6$

\begin{tabular}{|c|c|c|c|c|c|}
\hline \multirow{2}{*}{$\begin{array}{l}\text { Bacterial } \\
\text { strain }\end{array}$} & \multicolumn{5}{|c|}{ ACC-deaminase ( $\alpha$-ketobutyrate $\mathrm{nmol} \mathrm{mg}^{-1} \mathrm{~h}^{-1}$ ) } \\
\hline & $0 \mathrm{mM} \mathrm{NaCl}$ & $\begin{array}{c}50 \mathrm{mM} \\
\mathrm{NaCl}\end{array}$ & $\begin{array}{c}100 \mathrm{mM} \\
\mathrm{NaCl}\end{array}$ & $\begin{array}{c}200 \mathrm{mM} \\
\mathrm{NaCl}\end{array}$ & $300 \mathrm{mM} \mathrm{NaCl}$ \\
\hline P. simiae AU & $98 \pm 1.3$ & $93.9 \pm 1$ & $86.1 .0 \pm 0.8$ & $79 \pm .5$ & $71.4 \pm .1 .0$ \\
\hline
\end{tabular}

Table.2 Effects of different treatment on various plant growth parameters of mungbean seedlings under non-stressed and $\mathrm{NaCl}$ salt stressed conditions

\begin{tabular}{cllll}
\hline Treatment & $\begin{array}{l}\text { Root length } \\
\text { (cm) }\end{array}$ & $\begin{array}{l}\text { Shoot length } \\
\text { (cm) }\end{array}$ & $\begin{array}{l}\text { Fresh } \\
\text { weight }(\mathbf{g})\end{array}$ & RWC (\%) \\
\hline T1 & $9.87 \pm .42$ & $24 \pm .44$ & $3.8 \pm .4$ & $61 \pm 3.3$ \\
T2 & $7.1 \pm .33$ & $18 \pm .30$ & $2.6 \pm 1.5$ & $57 \pm 2$ \\
T3 & $5.0 \pm .26$ & $11 \pm 0.26$ & $1.4 \pm 0.7$ & $53 \pm 4.1$ \\
T4 & $11.0 \pm .48 * *$ & $25.5 \pm .56 * *$ & $4.2 \pm 0.8 * *$ & $72 \pm 3.5 * * *$ \\
T5 & $9.3 \pm .4 * * *$ & $21 \pm .5 * * *$ & $3 \pm 1.4 * * *$ & $60 \pm 3.3 * * *$ \\
T6 & $8.5 \pm .5 * * * *$ & $16.0 \pm 2 * * * *$ & $2.4 \pm 1.5 * * * *$ & $56 \pm 3.1 * * *$ \\
\hline
\end{tabular}

RWC represents relative water content. Data were analyzed by Two way ANOVA analysis followed by Tukey's multiple comparison test. Values represent the means $\pm \mathrm{SD}, \mathrm{n}=6$. Asterisks denoting $P$ value of significance (** $P \leq 0.01$; *** $P \leq 0.001$; **** $P \leq 0.0001)$. 
Fig.1 Effect of different treatment on free proline ( $\mu \mathrm{g} / \mathrm{g} \mathrm{FW})$ and total soluble sugars content $(\mu \mathrm{g} / \mathrm{g} \mathrm{FW})$ in mung bean seedlings. Where T1-control; T2- $100 \mathrm{mM} \mathrm{NaCl}$; T3- 200mM NaCl;

T4- AU inoculated; T5- AU + 100mM NaCl; T6- AU inoculated + 200mM NaCl. Values represent the means $\pm \mathrm{SD}, \mathrm{n}=6$

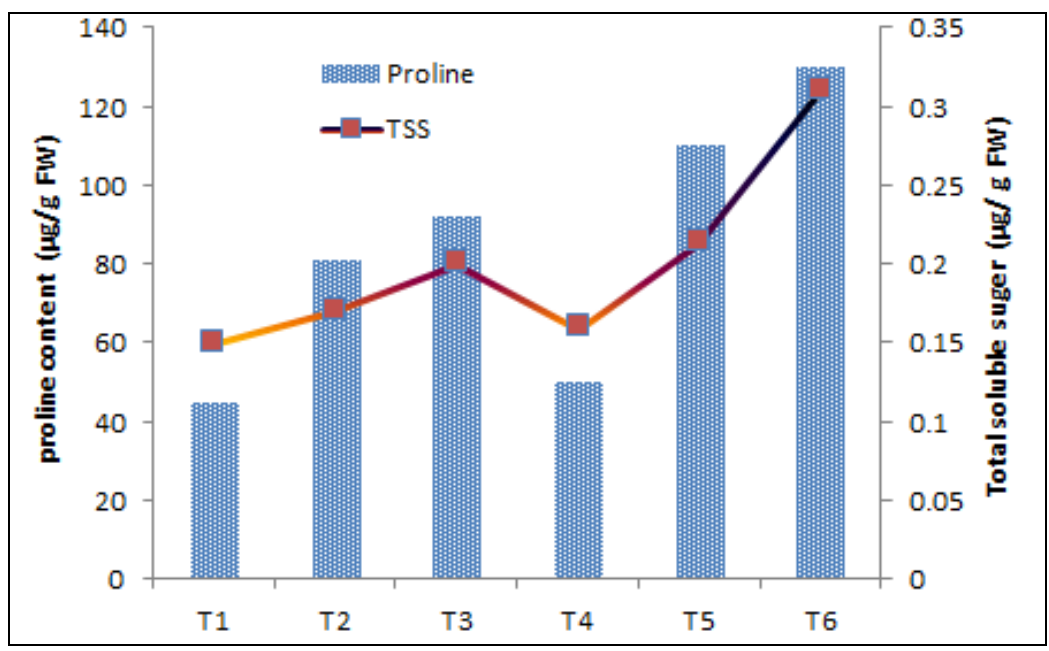

Fig.2 Effect of salinity stress on ethylene level in mungbean seedlings under different treatments.

Where T1-control, T2- 100mM NaCl, T3- 200mM NaCl; T5- AU + 100mM NaCl; T6- AU inoculated $+200 \mathrm{mM} \mathrm{NaCl}$. Data were analyzed by One way ANOVA analysis followed by DMRT test at $\mathrm{P}=0.05$. Values represent the means $\pm \mathrm{SD}, \mathrm{n}=6$.

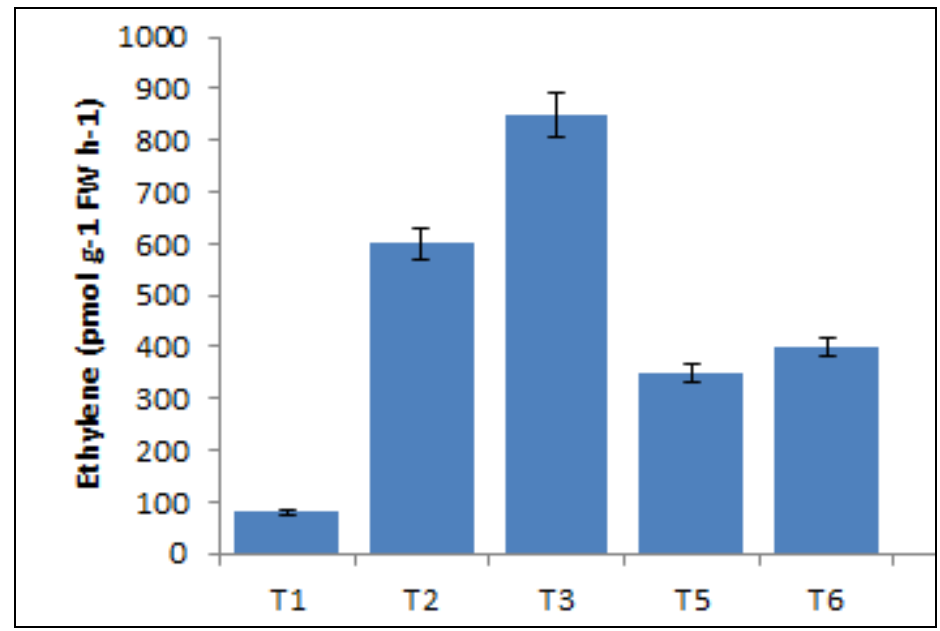

A high level of proline under abiotic stresse has been reported in the presence of beneficial bacteria such as, Burkholderia (Porcel and Ruiz-Lozano2004), Arthrobacter (Sziderics et al., 2007) and Bacillus (Gururani et al., 2013). Salinity stress induced the accumulation of soluble sugars in the plants that are contributed to the plant tolerance under salt stressed condition (Trotel-Aziz et al., 2000). In reference to above statement, bacterial treated seedlings showed increase TSS and proline content in their root during salt stressed condition (Fig.1). In this study ACC-deaminase eliminate the "salt stress imposed effects" on root and shoot growth were evident from the data documented. It was also observed that inoculation with 
PGPB containing ACC-deaminase was effective in increasing water use efficiency in peas under drought stress conditions (Ali et al., 2014). This verifies that ACCdeaminase breakdown the ACC level which results in the lower level of ethylene, the best results were found with AU inoculation (Fig. 2). Belimov et al., (2002) and Penrose et al., (2001) also studied the ability of ACC-utilizing PGPB to improve plant growth inhibition caused by stress ethylene through decrease ACC content in plant tissue.

In conclusion, the overall data shows that plant tissues are highly influenced by bacterium AU by means of induced systemic tolerance mechanisms against salt stress. It seems that the AU enhances osmotic adjustment by the accumulation of osmolytes and inhibition of stress ethylene level in plant tissue which could contribute to maintaining water potential encouraging to the water movement from soil into the roots. So, the inoculation of pseudomonas simiae strain AU through may improve the salt tolerance and enhance plant growth.

\section{Acknowledgments}

The research was supported by SERB-Grant no. SR/FT/LS-129/2012 to DKC. Some of the research has partially been supported by DBT grant no. BT/PR1231/AGR/21/340 /2011 to DKC. Authors would also like to thanks to Dr. Ajay kumar, Advanced Instrumentation Research Facility (AIRF, JNU), New Delhi for GC analysis.

\section{References}

Ahmad, M., Zahir, Z.A., Asghar, H.N., Asghar, M. 2011. Inducing salt tolerance in mung bean through co-inoculation with rhizobia and plant-growth-promoting rhizobacteria containing 1-aminocyclopropane-1carboxylate-deaminase. Can. J. Microbiol., 57: 578-589.
Ali, S.Z., Vardhrajula, S., Rao, V.L. 2014. Isolation and characterization of droughttolerant ACC deaminase and exopolysaccharide producing fluorescent Pseudomonas sp. Ann. Microbiol., 64:493502.

Banu, M.N.A., Hoque, M.A., WatanabeSugimoto, M., Matsuoka, K., Nakamura, Y., Shimoishi, Y., Murataa, Y. 2009. Proline and glycinebetaine induce antioxidant defense gene expression and suppress cell death in cultured tobacco cells under salt stress. J. Plant Physiol., 166:146-156.

Barka, E.A., Nowak, J., Clement, C. 2006. Enhancement of chilling resistance of inoculated grapevine plantlets with a plant growth promoting rhizobacterium Burkholderia phytofirman sstrain PsJN. Appl. Environ. Microbiol., 72:7246-7252.

Bates, L.S., Waldren, R.P., Teare, I.D. 1973. Rapid determination of free proline for water- stress studies. Plant Soil, 39:205207.

Belimov, A.A., Dodd, I.C., Hontzeas, N., Theobald, J.C., Safronova, V.I., Davies, W.J. 2009. Rhizosphere bacteria containing 1-aminocyclopropane-1-carboxylate deaminase increase yield of plants grow in drying soil via both local and systemic hormone signaling. New Phytol., 181:413423.

Belimov, A.A., Safronova, V.I., Sergeyeva, T.A., Egorova, T.N., Matveyeva, V.A., Tsyganov, V.E., Borosov, A.Y., Tikhonovich, I.A., Kluge, C., Preisfeld, A., Dietz, K.J., Stepanok, V.V. 2001. Characterization of plant growth promoting rhizobacteria isolated from polluted soils and containing 1-aminocyclopropane-1carboxylate deaminase. Can. J. Microbiol., 47, 242-252.

Dworkin, M., Foster, J. 1958. Experiments with some microorganisms which utilize ethane and hydrogen. J. Bacteriol., 75(5):592603.

Ghosh, S., Penterman, J.N., Little, R.D., Chavez, R., Glick, B.R. 2003. Three newly isolated plant growth promoting bacilli facilitate the seedling growth of canola, Brassica 
campestris. Plant Physiol. Biochem., 41:277-281.

Glick, B.R. 2004. Bacterial ACC deaminase and the alleviation of plant stress. Adv. Appl. Microbiol., 56: 291-312.

Glick, B.R. 2012. Plant Growth-Promoting Bacteria: Mechanisms and Applications. Scientifica doi:10.6064/2012/963401.

Glick, B.R., Penrose, D.M., Li, J. 1998. A model for the lowering of plant ethylene concentrations by plant growth-promoting bacteria. J. Theo. Biol., 190:63-68.

Gururani, M.A., Upadhyaya, C.P., Baskar, V., Venkatesh, J., Nookaraju, A., Park, S.W. 2013. Plant growth-promoting rhizobacteria enhance abiotic stress tolerance in Solanum tuberosum through inducing changes in the expression of ROS-scavenging enzymes and improved photosynthetic performance. J. Plant Growth Regul., 32: 245-258.

Hirsch, A.M., Fang, Y. 1994. Plant hormones and nodulation: what's the connection? Plant Mol Bio. 26: 5-9.

Irigoyen, J.J., Emerich, D.W., Sanchez-Diaz, M. 1992. Water stress induced changes in concentrations of proline and total soluble sugars in nodulated alfalfa (Medicago sativa) plants. Physiol Plant 84:55-60.

Kumari, S., Vaishnav, A., Jain, S., Varma, A., Choudhary, D.K. 2015. Bacterial-mediated induction of systemic tolerance to salinity with expression of stress alleviating enzymes in soybean (Glycine max L.Merrill).J. Plant Growth Regul., 10.1007/s00344-015-9490.

Mayak, S., Tirosh, T., Glick, B.R. 2004a Plant growth-promoting bacteria confer resistance in tomato plants to salt stress. Plant Physiol. and Biochem., 42:565-572.
Mayak, S., Tirosh, T., Glick, B.R. 2004b. Plant growth-promoting bacteria that confer resistance to water stress in tomatoes and peppers. Plant Sci., 166:525-530.

Penrose, D.M., Glick, B.R. 2003. Methods for isolating and characterizing ACC deaminase-containing plant growthpromoting rhizobacteria. Physiol. Plant, 118:10-5.

Penrose, D.M., Moffatt, B.A., Glick, B.R. 2001. Determination of 1-aminocyclopropane-1carboxylic acid (ACC) to assess the effects of ACC deaminase-containing bacteria on roots of canola seedlings. Can. J. Microbiol., 47:77-80

Pierik, R., Tholen, D., Poorter, H., Visser, E.J.W., Voesenek, L.A.C.J. 2006. The Janus face of ethylene: growth inhibition and stimulation. Trends Plant Sci., 11:17683.

Porcel, R., Barea, J.M., Ruiz-Lozano, J.M. 2004. Arbuscular mycorrhizal influence on leaf water potential, solute accumulation, and oxidative stress in soybean plants subjected to drought stress. J. Exp. Bot., 55(403): 1743-1750.

Sziderics, A.H., Rasche, F., Trognitz, F., Sessitsch, A., Wilhelm, E. 2007. Bacterial endophytes contribute to abiotic stress adaptation in pepper plants (Capsicum annuum L.). Can. J. Microbiol., 53:11951202.

Trotel-Aziz, P., Niogret, M.F., Larher, F. 2000. Proline level is partly under the control of abscisic acid in canola leaf discs during recovery from hyper-osmotic stress. Physiol. Plant, 110:376-383.

Yang, S.F., Hoffman, N.E. 1984. Ethylene biosynthesis and its regulation in higher plants. Annu. Rev. Plant Physiol., 35: 155189.

\section{How to cite this article:}

Sarita Kumari, Anukool Vaishnav, Shekhar Jain, Devendra Kumar Choudhary and Kanti Prakash Sharma. 2016. Regulation of Ethylene Level in Mungbean (Vigna radiata L.) by 1Aminocyclopropane-1-Carboxylic Acid (ACC)-Deaminase containing Bacterial Strain under Salt Stress. Int.J.Curr.Microbiol.App.Sci. 5(11): 275-283.

doi: http://dx.doi.org/10.20546/ijcmas.2016.511.030 